\title{
Genotypic identification of coliforms isolated from cases of subclinical mastitis among pastoral herds in parts of Kaduna State, Nigeria
}

\author{
1, 2* Makolo, D., ${ }^{2}$ Suleiman, A. B., ${ }^{2}$ Olonitola' O. S., ${ }^{3}$ Bello, M., and ${ }^{4}$ Ahmadu, I. \\ ${ }^{1}$ Department of Sciences, School of Preliminary Studies, Kogi State Polytechnic, Lokoja, Nigeria \\ ${ }^{2}$ Department of Microbiology, Faculty of Life Sciences, Ahmadu Bello University, Zaria, Nigeria \\ ${ }^{3}$ Department of Veterinary Public Health and Preventive Medicine, Faculty of Veterinary Medicine, \\ Ahmadu Bello University, Zaria, Nigeria \\ ${ }^{4}$ National Tuberculosis Reference Laboratory, Zaria, Nigeria \\ *Correspondence to: makolodaniel@gmail.com
}

\begin{abstract}
:
Background: Mastitis caused by Staphylococcus aureus was initially considered the major problem in dairy herds, but over the last few decades, the incidence of coliform mastitis has increased among the pastoral herds in Nigeria due to poor environmental and milking hygiene. Hence, this study was aimed at genotypic identification of coliform bacteria isolated from cases of bovine mastitis among pastoral herds in parts of Kaduna State, Nigeria.

Methods: A cross-sectional survey of 30 herds of cows across 7 Local Government Areas of Kaduna State, Nigeria, was conducted. One hundred and forty seven cows were proportionately selected by purposive sampling technique. The milk samples were aseptically collected and bacteriologically screened for coliform bacteria following standard bacteriological techniques. Nine out of 12 coliforms identified phenotypically were selected for PCR amplification and sequencing of their 16S rRNA gene. The Basic Local Alignment Search Tool (BLAST) analysis of the sequences obtained was done on the National Centre for Biotechnology Information (NCBI) data base, and isolates confirmed based on similarity to $16 \mathrm{~S}$ rDNA sequences in the Gen Bank

Results: Five of the 9 coliforms were confirmed to be Klebsiella pneumoniae (prevalence rate, 3.4\%) and 4 were confirmed to be Escherichia coli (prevalence rate, 2.7\%).

Conclusion: This study shows that raw milk of mastitic cows can serve as a vehicle for the spread of pathogens such as K. pneumoniae and E. coli which, according to the Department of Health and Human Services of the United States Public Health Services, are potential threats to public health and safety of humans, animals and plant products.
\end{abstract}

Keywords: pastoral herds, subclinical mastitis, cows, PCR, 16s rRNA, sequencing

Received July 30, 2019; Revised October 19, 2019; Accepted October 20, 2019

Copyright 2020 AJCEM Open Access. This article is licensed and distributed under the terms of the Creative Commons Attrition 4.0 International License (http://creativecommmons.org/licenses/by/4.0), which permits unrestricted use, distribution and reproduction in any medium, provided credit is given to the original author(s) and the source.

\section{Identification génotypique de coliformes isolés à partir de cas de mammites subcliniques parmi des troupeaux pastoraux dans certaines parties de l'État de Kaduna, au Nigéria}

\author{
1,2* Makolo, D., ${ }^{2}$ Suleiman, A. B., ${ }^{2}$ Olonitola, O. S., ${ }^{3}$ Bello, M., et ${ }^{4}$ Ahmadu, I.
}

\footnotetext{
${ }^{1}$ Département des sciences, École d'études préliminaires, École polytechnique d'État de Kogi, Lokoja, Nigéria

${ }^{2}$ Département de microbiologie, Faculté des sciences de la vie, Université Ahmadu Bello, Zaria, Nigéria.

${ }^{3}$ Département de santé publique vétérinaire et médecine préventive, Faculté de médecine vétérinaire, Université Ahmadu Bello, Zaria, Nigeria

${ }^{4}$ Laboratoire national de référence pour la tuberculose, Zaria, Nigeria

*Correspondance à: makolodaniel@gmail.com
} 


\begin{abstract}
Abstrait:
Contexte: La mammite causée par Staphylococcus aureus était à I'origine considérée comme le principal problème des troupeaux laitiers, mais au cours des dernières décennies, l'incidence de la mammite à coliformes a augmenté dans les troupeaux pastoraux du Nigéria en raison de la mauvaise hygiène de l'environnement et de la traite. Par conséquent, cette étude visait l'identification génotypique de bactéries coliformes isolées à partir de cas de mammite bovine parmi les troupeaux pastoraux dans certaines parties de l'État de Kaduna, au Nigéria. Méthodes: Une enquête transversale sur 30 troupeaux de vaches dans 7 zones de gouvernement local de l'État de Kaduna au Nigéria a été réalisée. Cent quarante sept vaches ont été sélectionnées proportionnellement par une technique d'échantillonnage raisonné. Les échantillons de lait ont été collectés de manière aseptique et soumis à un dépistage bactériologique des bactéries coliformes selon les techniques bactériologiques classiques. Neuf des 12 coliformes identifiés phénotypiquement ont été sélectionnés pour l'amplification par PCR et le séquençage de leur gène ARNr 16S. L'analyse par l'outil de recherche d'alignement local de base (BLAST) des séquences obtenues a été effectuée sur la base de données du Centre national d'information sur la biotechnologie (NCBI), et des isolats ont été confirmés sur la base de la similarité avec les séquences d'ADNr 165 de la banque de gènes.

Résultats: Klebsiella pneumoniae a été confirmé chez cinq des neuf coliformes (taux de prévalence de 3,4\%) et dans 4 cas chez Escherichia coli (taux de prévalence de 2,7\%).

Conclusion: cette étude montre que le lait cru de vaches mastitiques peut servir de vecteur à la propagation d'agents pathogènes tels que K. pneumoniae et $\mathrm{E}$. coli qui, selon le ministère de la Santé et des Services sociaux des Etats-Unis, sont: menaces potentielles pour la santé publique et la sécurité des personnes, des animaux et des produits végétaux.
\end{abstract}

Mots-clés: troupeaux pastoraux, mammite subclinique, vaches, PCR, ARNr 16s, séquençage

\title{
Introduction:
}

The genera of coliforms mostly implicated in cases of bovine mastitis are Klebsiella, Escherichia, and Enterobacter. However, the most frequently isolated species of coliform bacteria are Klebsiella pneumoniae and Escherichia coli (1, 2). Furthermore, coliforms are not natural inhabitants of the mammary gland, but many strains are capable of surviving and multiplying there. Hence, intramammary infections caused by coliforms and other Gram-negative bacteria typically result from the bacteria that traverse the teat canal and multiply in the gland $(1,2,3)$.

Klebsiella pneumoniae is one of the known causes of primarily environment derived Klebsiella mastitis and has been the subject of numerous studies $(4,5) . K$. pneumoniae is an opportunistic human pathogen mainly affecting immunocompromised or elderly patients. Recently a hyper-virulent $K$. pneumoniae strain was reported to be capable of causing fatal infections in healthy individuals (6). $K$. pneumoniae has been reported in different countries in serious outbreaks or in isolated cases of per-acute or acute bovine mastitis, predominantly in the first two weeks of lactation. Mammary infections are often associated with wood or sawdust contamination used in the environment of the animals $(4,7,8)$.

Since the 1980s there has been a presence of individuals with community acquired $K$. pneumoniae infections resulting in primary liver abscesses. These liver abscesses are caused by the capsular serotype $\mathrm{K} 1$ and the gene magA (9). This gene is believed to be involved in exo-polysaccharide biosynthesis which can protect the bacteria and contribute to its virulence. All isolates containing the magA gene were all serotype $\mathrm{K} 1$ which leads researchers to believe that the $\mathrm{K} 1$ capsular serotype is an important virulence factor (9).

Escherichia coli are parts of the normal microbiota of the gut, and can benefit their hosts by producing vitamin $\mathrm{K}_{2}$ (10) and preventing colonization of the intestine by other pathogenic bacteria, having a symbiotic relationship $(11,12)$. E. coli is released into the environment within fecal matter. The bacterium grows massively in fresh fecal matter under aerobic condition for three days and declines gradually afterwards (13). E. coli is one of the main causative agents of bovine mastitis which is responsible for significant losses on dairy farms that is of great economic interest $(14,15,16)$. Most $E$. coli strains do not cause disease, but virulent strains can cause gastroenteritis, urinary tract infections, neonatal meningitis, and haemorrhagic colitis (17). Common signs and symptoms include severe abdominal cramps, diarrhoea, haematochezia, vomiting, and sometimes fever. In rare cases, virulent strains are also responsible for bowel necrosis and perforation without progressing to hemolytic-uremic syndrome, peritonitis, mastitis, septicemia, and Gram-negative pneumonia (18). Young children are more vulnerable to develop severe illness, such as hemolytic uremic syndrome; however, healthy individuals of all ages are at 
risk to the severe consequences that arises as a consequence of being infected with $E$. coli $(17,18)$.

In the 1960s, Dubnau et al., (19) noted conservation in the 16S rRNA gene sequence relationships in Bacillus spp. The extensive use of this gene sequence for bacterial identification and taxonomy followed a body of pioneering work by Woese, who defined important properties. Foremost is the fact that it seems to behave as a molecular chronometer, as pointed out in an excellent review article by Woese (20). Furthermore, no gene has shown as broad applicability over all the taxonomic groups as the $16 \mathrm{~S}$ rRNA gene. Thus, if the goal is to identify an unknown organism on the basis of no prior knowledge, the 16S rRNA gene sequence is an excellent and extensively used choice (21). The $16 \mathrm{~S}$ rRNA gene sequence has been determined for a large number of bacterial strains. Gen Bank, the largest databank of nucleotide sequences, has over 20 million deposited sequences, of which over 90,000 are of 165 rRNA gene (21). The 16S rRNA gene is universal in bacteria, and so relationships can be measured among all bacteria $(22,20,21)$. Hence, this study was carried out to confirm some coliform bacteria isolated from cases of subclinical mastitis by PCR amplification of the 16S rRNA gene and direct nucleotide sequencing.

\section{Materials and method:}

\section{Study area and population}

The study area, which is same as in a previous study by Makolo et al., (23), involved settlements in each of 7 Local Government Areas of Kaduna State, Nigeria; Chikun, Igabi, Soba, Birnin Gwari, Sabongari, Zaria and Giwa (Fig. 1). One hundred and forty seven lactating cows were proportionately selected by purposive sampling technique among 309 within 30 pastoral herds (Table 1 ).

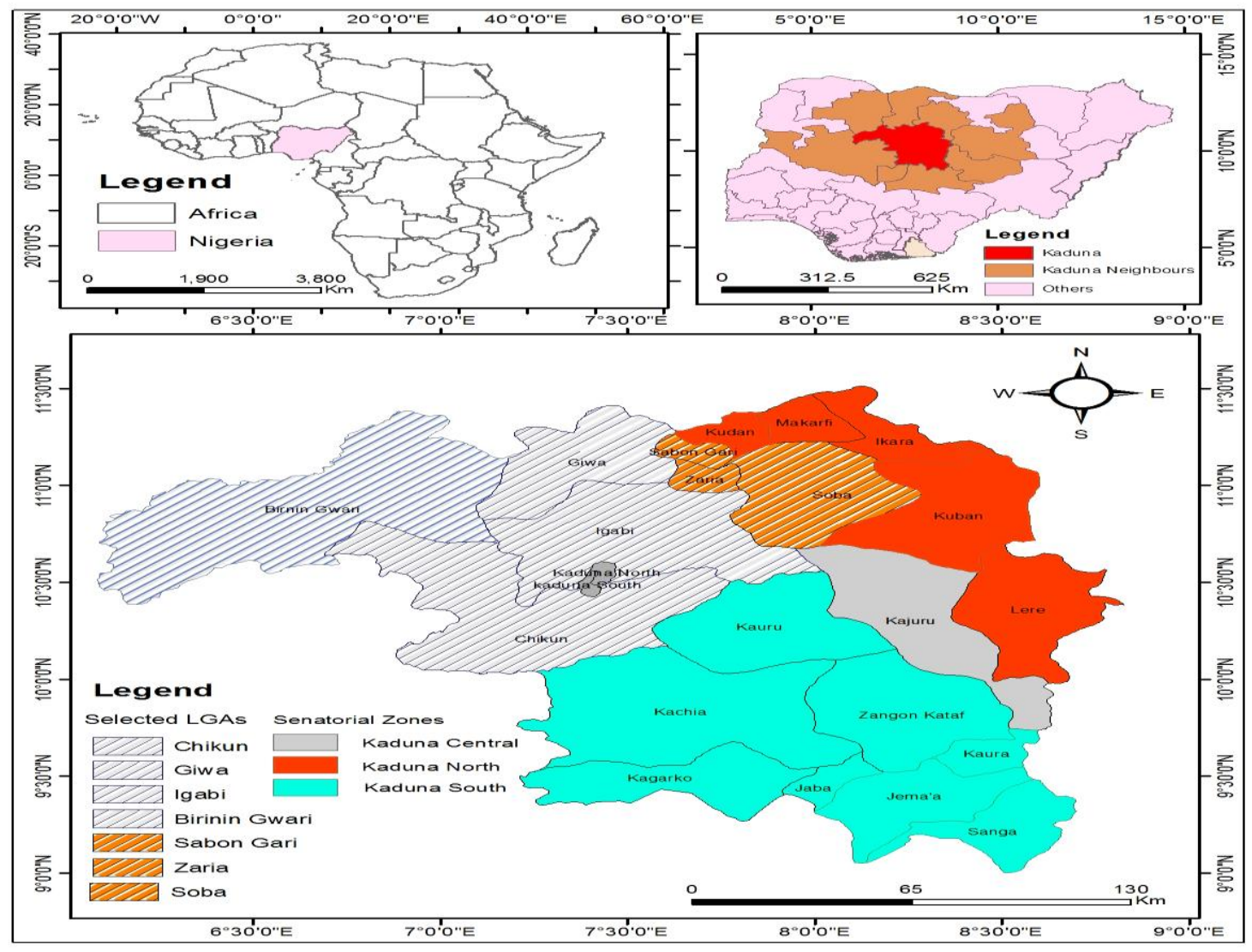

Fig 1: Map of Africa, Nigeria and Kaduna State showing the study area Source: Makolo et al. (23) 
Table 1: Proportionate distribution of samples across the study population

\begin{tabular}{clccc}
\hline S/N & Local Government Area/Settlements & No. of Herds & $\begin{array}{c}\text { No. of Lactating } \\
\text { Cows }\end{array}$ & $\begin{array}{c}\text { No. of Cows } \\
\text { Examined }\end{array}$ \\
\hline 1. & Giwa (Settlement A) & 5 & 50 & 24 \\
2. & Igabi (Settlement B) & 3 & 30 & 15 \\
3. & Chikun (Settlement C) & 4 & 39 & 19 \\
4. & Soba (Settlement D) & 3 & 27 & 12 \\
5. & Zaria (Settlement E) & 5 & 55 & 26 \\
6. & Sabongari (Settlement F) & 4 & 40 & 19 \\
7. & Birnin Gwari (Settlement G) & 6 & 68 & 32 \\
\multicolumn{2}{r}{ Source: Makolo et al., (23) } & 30 & 309 & \\
\end{tabular}

\section{Bacteria isolates}

Nine coliform isolates recovered from cows with mastitis in the previous study and stored in the Microbiology Laboratory of Ahmadu Bello University, Zaria were selected for the study. These isolates have been previously identified as coliform bacteria using the conventional biochemical tests and Microgen identification kit (23).

\section{DNA extraction from coliform isolates}

Genomic DNA was extracted using DNA Miniprep; $100 \mathrm{mg}$ (wet weight) of bacterial cells were re-suspended in a tube containing $200 \mu \mathrm{L}$ of isotonic buffer (Applied Biosystems, USA), and $750 \mu \mathrm{L}$ lysis solution was added to the tube. This was secured in a bead fitted with $2 \mathrm{ml}$ tube holder assembly and processed at maximum speed for 5 minutes. The mixture in the ZR Bashing Bead ${ }^{\mathrm{TM}}$ Lysis Tube was centrifuged in a microcentrifuge at 10,000xg for 1 minute. Exactly $400 \mu \mathrm{L}$ of the supernatant was transferred to a Zymo-Spin ${ }^{\mathrm{TM}}$ IV Spin Filter (orange top) in a collection tube and centrifuged at $7,000 \times \mathrm{xg}$ for 1 minute. Then, $1,200 \mu \mathrm{L}$ of bacterial DNA binding buffer was added to the filtrate in the collection tube after which $800 \mu \mathrm{L}$ of the mixture was transferred to a Zymo-Spin ${ }^{\mathrm{TM}}$ IIC Column in a collection tube and centrifuged at $10,000 \times \mathrm{xg}$ for 1 minute.

The flow through from the collection tube was discarded and 200uL DNA pre-wash buffer was added to the Zymo-Spin TM IIC Column in a new collection tube and centrifuged once again at $10,000 \times \mathrm{xg}$ for 1 minute. Then, 500 $\mu \mathrm{L}$ bacterial DNA wash buffer was added to the Zymo-Spin ${ }^{\mathrm{TM}}$ IIC Column and centrifuged at $10,000 \times \mathrm{xg}$ for 1 minute. The mixture from Zymo-Spin ${ }^{\mathrm{TM}}$ IIC Column was transferred to a clean $1.5 \mathrm{ml}$ microcentrifuge tube and $100 \mu \mathrm{L}$ DNA elution buffer was added directly to the column matrix. This was centrifuged at $10,000 \times \mathrm{xg}$ for 30 seconds to elute the genomic DNA for PCR and sequencing.

\section{DNA quantification}

The extracted genomic DNA was quantified using the NanoDrop 1000 Spectrophotometer at the wavelength of $260 / 280 n m$. Briefly, the upper and lower optical surfaces of the micro volume spectrophotometer sample retention system was cleaned by pipetting $3 \mu \mathrm{L}$ of clean deionized water onto the lower optical surface. The lower arm was closed, ensuring that the upper pedestal came in contact with the deionized water. The lower arm was lifted and both optical surfaces were wiped off with a clean, dry, lint-free lab wipe. Then, the NanoDrop software was opened and 'nucleic acid application' was selected.

Using a small volume calibrated pipettor, $1 \mu \mathrm{L}$ of buffer was measured onto the lower optical surface. The lever arm was lowered and 'blank' was selected in the nucleic acid application. Constant of $260-280 \mathrm{~nm}$ was selected for the DNA samples to be measured. Then, $1 \mu \mathrm{L}$ of nucleic acid sample was dispensed onto the lower optical pedestal and the lever arm was closed. The 'measure' was selected in the application software which automatically measured the nucleic acid and purity ratios.

\section{PCR assay}

A $10 \mu \mathrm{L}$ reaction mixture was used for DNA amplification by PCR which contained $1.0 \mu \mathrm{L}$ of PCR buffer, $1.0 \mu \mathrm{L}$ of $\mathrm{MgCl}_{2}, 0.5 \mu \mathrm{L}$ of forward primer (5'-GTGCCAGCAGCCGCGCTAA$\left.3^{\prime}\right), 0.5 \mu \mathrm{L}$ of reverse primer (5'-AGACCCG GGAACGTATTCAC- $\left.3^{\prime}\right), 1.0 \mu \mathrm{L}$ of DMSO, $0.8 \mu \mathrm{L}$ of dNTPs $(2.5 \mathrm{Mm}), 0.1 \mu \mathrm{L}$ of Taq DNA polymerase $(5 \mathrm{U} / \mu \mathrm{L}), 2.0 \mu \mathrm{L}$ of template DNA $(10 \mathrm{ng} / \mu \mathrm{L})$ and $3.1 \mu \mathrm{L}$ distilled water. DNA amplification was carried out in a thermocycler (ABI- 
PRISM $^{\circledR} 3700$ Genetic Analyzer) with a precycle at $94^{\circ} \mathrm{C}$ for 5 minutes, 36 cycles of denaturation at $94^{\circ} \mathrm{C}$ for $30 \mathrm{sec}$, annealing at $56^{\circ} \mathrm{C}$ for $30 \mathrm{sec}$, extension at $72^{\circ} \mathrm{C}$ for $45 \mathrm{sec}$, and final extension at $72^{\circ} \mathrm{C}$ for $7 \mathrm{~min}$ with expected amplicon size of 850bp (24).

Agarose gel electrophoresis of PCR products The amplified PCR products of the coliform bacteria were loaded on $1.5 \%$ agarose gel and electrophoresed at $120 \mathrm{~V}$ for 15 minutes along with a 100bp ladder (Bioline, USA) and negative control (nuclease free water). The gels were stained with ethidium bromide and observed UV transillumination, and photographed.

\section{PCR product purification}

The PCR product was purified by adding $20 \mu \mathrm{L}$ of absolute ethanol to the PCR product and incubating at room temperature for 15 minutes. The product was spun at 1,000 rpm for 15 minutes. With the supernatant decanted and spun again at 1,000rpm for 15 minutes. Then, $40 \mu \mathrm{L}$ of $70 \%$ ethanol was added supernatant was decanted and air dried. About $10 \mu \mathrm{L}$ of ultrapure water was added and the amplicon was checked on $1.5 \%$ agarose.

\section{Sequencing of PCR products}

The PCR products were sequenced using the Big Dye Terminator Kit on ABI-PRISM 3700 Genetic Analyzer (Applied Biosystems, USA) at the Biosciences Centre, International
Institute of Tropical Agriculture (IITA), Ibadan, Nigeria.

Basic Local Alignment Search Tool (BLAST)
analysis of gene sequences
The BLAST analysis was carried out on the gene sequences obtained using the online database of National Centre for Biotechnology Information: http://blast.ncbi.nlm.nih.gov./Blast.cgi. Briefly, the gene sequences per organism were copied from the FASTA file format and paste in the Blast Window online where Nucleotide Sequence Blast was selected. The result showed the lineage report on the organism identified and the sequences producing significant alignments with those deposited in the Gene Bank. Interpretation of results was done following the instructions of NCBI.

\section{Results:}

Table 2 shows the result of quantitative analysis of the extracted DNA of the coliform isolates using spectrophotometer at the wavelength of $260 / 280 \mathrm{~nm}$. The result revealed that the DNA extraction of all the isolates fell within the acceptable standard (1.6-1.9) of quality and purity for PCR and sequence analysis. All the 9 coliform isolates amplified on PCR of $16 S$ rRNA genes (Fig 2). The 16S rRNA PCR sequencing confirmed the isolates to be Klebsiella pneumoniae $(\mathrm{n}=5)$ and Escherichia coli $(\mathrm{n}=4)$ (Table 3$)$.

Table 2: Quantification of the extracted DNA from coliform isolates by Spectrophotometer at the wavelength of $260 / 280 \mathrm{~nm}$

\begin{tabular}{ccc}
\hline Sample identity & Concentration & Purity \\
\hline E1 & 87.7 & 1.76 \\
E3 & 47.9 & 1.85 \\
E4 & 40.7 & 1.77 \\
K1 & 87.7 & 1.81 \\
K2 & 31.9 & 1.86 \\
K4 & 119.9 & 1.8 \\
K6 & 59.2 & 1.8 \\
K7 & 36.5 & 1.86 \\
P1 & 90.6 & 1.83 \\
\hline
\end{tabular}

E1-E4 and P1 = Escherichia coli isolate; K1-K7 = Klebsiella pneumoniae isolates 


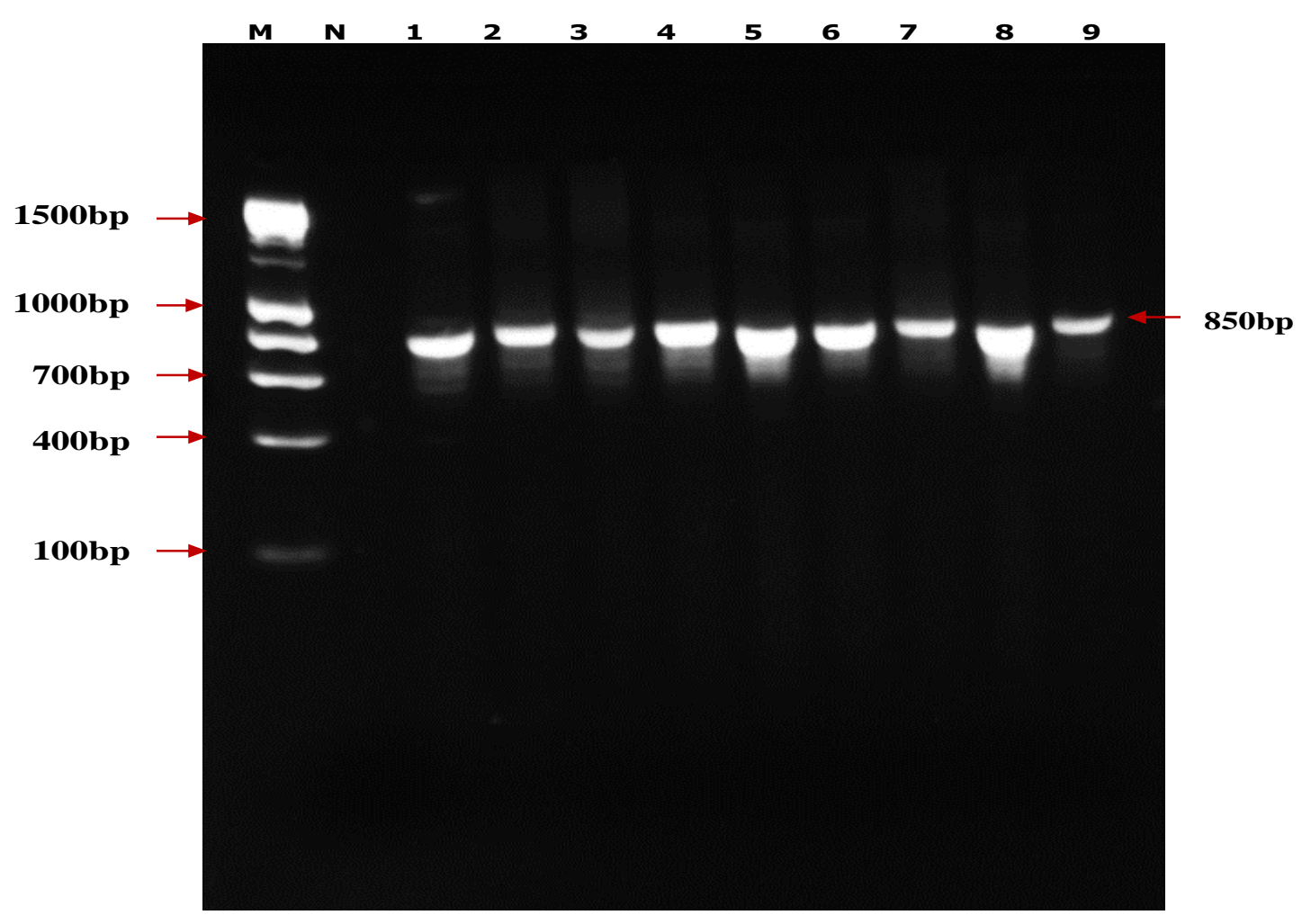

Fig 2: Amplified fragment of 165 rRNA gene of coliform isolates (850bp)

Lane M (Molecular Marker of 100bp); Lane N (Nuclease free water as negative control); Lanes 1, 4, 5, 6, and 8 (Klebsiella pneumoniae isolates); Lanes $2,3,7$, and 9 (Escherichia coli isolates)

Table 3: BLAST analysis of 16S rRNA sequences of coliforms with the GenBank database of National Centre for Biotechnological Information

\begin{tabular}{|c|c|c|c|c|c|}
\hline $\begin{array}{l}\text { Isolates } \\
\text { Code }\end{array}$ & $\begin{array}{l}\text { Genotypic } \\
\text { identification }\end{array}$ & $\begin{array}{c}\text { Sequence with significant } \\
\text { alignment }\end{array}$ & E-value & QC & ID \\
\hline E1 & Escherichia coli & Escherichia coli strainASRM93 & 0.0 & $95 \%$ & $100 \%$ \\
\hline E 3 & Escherichia coli & Escherichia coli strain AMUM1 & 0.0 & $97 \%$ & $99 \%$ \\
\hline E 4 & Escherichia coli & Escherichia coli strain NF113 & 0.0 & $97 \%$ & $94 \%$ \\
\hline $\mathrm{K} 1$ & $\begin{array}{l}\text { Klebsiella } \\
\text { pneumoniae }\end{array}$ & Klebsiella pneumoniae strain $\mathrm{MH} 18$ & 0.0 & $97 \%$ & $99 \%$ \\
\hline $\mathrm{K} 2$ & $\begin{array}{c}\text { Klebsiella } \\
\text { pneumoniae }\end{array}$ & Klebsiella pneumoniae strain NF16 & 0.0 & $97 \%$ & $99 \%$ \\
\hline K4 & $\begin{array}{c}\text { Klebsiella } \\
\text { pneumoniae }\end{array}$ & Klebsiella pneumoniae strain NF15 & 0.0 & $95 \%$ & $100 \%$ \\
\hline K6 & $\begin{array}{c}\text { Klebsiella } \\
\text { pneumoniae }\end{array}$ & Klebsiella pneumoniae strain Ma19 & 0.0 & $97 \%$ & $99 \%$ \\
\hline K7 & $\begin{array}{c}\text { Klebsiella } \\
\text { pneumoniae }\end{array}$ & Klebsiella pneumoniae strain NF82 & 0.0 & $97 \%$ & $98 \%$ \\
\hline $\mathrm{P} 1$ & Escherichia coli & Escherichia coli strain 244 & 0.0 & $96 \%$ & $99 \%$ \\
\hline
\end{tabular}

\section{Discussion:}

This study has established that coliform bacteria were associated with cases of subclinical mastitis among the investigated cows from pastoral herds in parts of Kaduna
State, Nigeria. This is similar with the report of Mbuk et al., (25) in Kaduna State, Nigeria, Junaidu et al., (26) in Sokoto, Nigeria, Agunbiade et al. (27) in Kaduna State, Nigeria, Hempen et al., (28) in Gambia, Senegal and Guinea, and Lingathurai and Vellathurai, (29) 
in Madurai, India who isolated coliforms from cases of bovine mastitis in similar studies.

The species of coliforms isolated in this study based on the genotypic identification were $K$. pneumoniae and $E$. coli with $K$. pneumoniae being the more frequent species associated with bovine mastitis. This is in agreement with the study of Mbuk et al., (25) who isolated similar species of these organisms in Kaduna State with $K$. pneumoniae being predominant and non $E$. coli was isolated. These findings also agree with the report of Hogan and Smith (1) and Podder et al., (30). Generally, the presence of these coliform bacteria in milk is an indication of feacal and environmental contamination resulting from poor hygienic practices of rearing and milking the animals as they are no established mastitis control practices employed among the herdsmen. This affirms the reports of the Centre for Disease Control (31), Food and Agricultural Organization (32), and other regulatory agencies around the world which reported that pathogens from raw milk including potential agents of diarrhoea, tuberculosis, diphtheria, typhoid and streptococcal infections make raw milk unsafe for consumption (33). Similarly, Claeys et al., (34) reported that consumption of raw milk poses a realistic health threat due to a possible contamination with human pathogens.

Furthermore, from epidemiological point of view, the presence of these organisms in the milk of cows reared for commercial purpose is of significant public health threat. This assertion is affirmed by the report of United States Public Health Services Department of Health and Human Services which listed all species and serotypes of Klebsiella, Proteus, Escherichia, Citrobacter, Enterobacter, Pantoea and Serratia as dangerous biological agents with potential threat to public health and safety of humans, animals and plant products (35). Consequently, the coliform species isolated in this study are part of this list. Therefore, consumption of raw milk from bovines with mastitis may pose serious health challenges to the populace.

The results of BLAST alignment revealed that the best match of the organisms isolated in this study based on sequence similarity with those in GenBank was within the range of $94-100 \%$. This significant correlation between these sequences implies close similarity in the gene sequences of the isolated coliform with their best match in GenBank. Therefore, from epidemiological point of view, the measure used in the control of the best match of these isolates in their various countries of origin may also be effective in controlling them within the current study population on the ground of homology (those with $100 \%$ similarity) which makes these strains to share the same structure and function. The BLAST results also revealed that the majority of these organisms that showed significant sequence alignments with those isolated in this study were from human sources. This affirms the findings of Hogan and Smith (1) that coliforms are not natural inhabitants of the bovine mammary gland, but are usually transmitted from humans and contaminated environment through poor hygienic process of milking and rearing the animals. Generally, this study affirms the previous reports that identifying bacteria by DNA sequencing instead of phenotype provide better identification of poorly described, rarely isolated, or biochemically aberrant strains.

\section{Conclusion:}

In conclusion, all 9 coliform bacteria previously identified by phenotypic methods were confirmed to be $K$. pneumoniae and $E$. coli based on significantly high similarity and best match with NCBI GenBank data. Consequently, the presence of $K$. pneumoniae and $E$. coli in raw milk samples of cows reared for commercial purposes poses a potential public health threat to the study population. Therefore, periodic investigations on the bacteriological quality of milk from pastoral herds and the health status of the cows should be given a priority to avoid the epidemics of food borne and zoonotic disease.

\section{Acknowledgments:}

The authors are grateful to the pastoralists who granted consent to study the animals and environment. The assistance of staff and management of National Commission for Nomadic Education, Kaduna State Office in assessing the pastoral herds is acknowledged. The authors appreciate the staff and management of the Biosciences Centre, International Institute of Tropical Agriculture (IITA), Ibadan, Nigeria for the molecular analysis. The Nigerian Tertiary Education Trust Fund (TETFUND) sponsored this study.

\section{Authors contributions:}

$A B S$ and $D M$ conceived and designed the study; ABS, MB and OSO provided critical intellectual content; DM and IA performed the 
laboratory analysis; DM and ABS analyzed the gene sequence data; IA contributed reagents, materials and analysis tools; and DM wrote the manuscript. All authors agreed to the final version of the manuscript.

\section{References:}

1. Hogan, J., and Smith, K. L. Coliform Mastitis. Vet Res. 2003; 34: 507 - 519.

2. Memon, J., Kashif, J., Yaqoob, M., Kiping, W., Yang, Y., and Hongjie, F. C. Molecular characterization and antimicrobial sensitivity of pathogens from subclinical mastitis in Eastern China. Pak Vet J. 2013; 33 (2): 170 - 174.

3. Shittu, A., Abdullahi, J., Jibril A., Mohammed A.A., and Fasino, F. O. Subclinical mastitis and associated risk factors in lactating cows in the Savannah Region of Nigeria. BMC Vet Res. 2012; 28: 134 .

4. Munoz, M. A., Welcome, F. L., Schukken, Y. H., and Zadoks, R. N. Molecular epidemiology of two Klebsiella pneumoniae mastitis outbreaks on a dairy farm in New York State. J Clin Microbiol. 2007; 45: 3964 - 3971

5. Zadoks, R. N., Middleton, J. R., McDougall, S., Katholm, J., and Schukken, Y. H. Molecular epidemiology of mastitis pathogens of dairy cattle and comparative relevance to humans. J Mam Glan Bio Neopl. 2011; 16: 357-372.

6. Shon, A. S, Bajwa, R. P, and Russo, T. A. Hypervirulent (hypermucoviscous) Klebsiella pneumoniae: a new and dangerous breed. Viru. 2013; 4: 107-118.

7. Wenz, J. R., Barrington, G. M., Garry, F. B. McSweeney, K. D., Dinsmore, R. P., Goodell, G., and Callan, R. J. Bacteremia associated with naturally occurring acute coliform mastitis in dairy cows. J Am Vet Med Assoc. 2001; 219: 976-981.

8. Radostis, O. M., Gay, C. C., Blood, D. C., and Hinchlif, K. W. Mastitis in Veterinary Medicine, $9^{\text {th }}$ ed. Harcourt Ltd, London. 2007; 174-758.

9. Jang, S., Wheeler, L., Carey, R., Jensen, B., Crandall, C., Schrader, K., Jessup, D., Colegrove, K., and Gulland, F. "Pleuritis and suppurative pneumonia associated with a hypermuco-viscosity phenotype of "Klebsiella pneumoniae" in California sea lions "Zalophus californianus" Vet Microbiol. 2010; 141: 174 - 177.

10. Blum, S., Heller, E. D., Krifucks, O., Sela, S., Hammer-Muntz, O., and Leitner, G. Identification of a bovine mastitis Escherichia coli subset. Vet Microbiol. 2008; 132 (1-2): 135-148.

11. Hudault, S., Guignot, J., and Servin, A. L. Escherichia coli strains colonizing the gastrointestinal tract and protect germfree mice against Salmonella typhimurium infections. Gut. 2001; 49 (1): 47-55.

12. Reid, G., Howard, J., and Gan, B. S. Can bacteria interference prevents infection? Trends Microbiol. $2001 ; 9$ (9): 8-424.

13. Russell, J. B., and Jarvis, G. N. Practical Mechanisms for interrupting the oral-fecal lifecycle of E. coli. J Mol Microbiol Biotechnol. 2001; 3 (2): 72-265.

14. Waage, S., Mørk, T., Røros, A., Aasland, D., Hunshamar, A., and Ødegaard, S. A. Bacteria associated with clinical mastitis in dairy heifers. J Dairy Sci. 1999; 182 (4): 712-719.

15. Halasa, T., Huijps, K., Osteras, O., and Hogeveen, $\mathrm{H}$. Economic effects of bovine mastitis and mastitis management. Rev Vet Quar. 2007; 29 (1): $18-31$.
16. Olde Riekerink, R. G., Barkema, H. W., Kelton, D. F., and Scholl, D. T. Incidence rate of clinical mastitis on Canadian dairy farms. J Dairy Sci. 2008; 91 (4): 1366-1377.

17. Todar, K. Pathogenic Escherichia coli. Online Textbook of Bacteriology. University of WisconsinMadison, Department of Bacteriology. 2007: 3467.

18. Lim, J. Y., Yoon, J., and Hovde, C. J. A brief overview of Escherichia coli 0157:H7 and its plasmid O157. J Microbiol Biotechnol. 2010; 20 (1): 5-14.

19. Dubnau, D., Smith, I., Morell, P., and Marmur, J. Gene conservation in Bacillus species. I. Conserved genetic and nucleic acid base sequence homologies. Proc Natl Acad Sci USA. 1965; 54: 491-498.

20. Woese, C. R. Bacterial evolution. Microbiol Rev 1987; 51: 221-271.

21. Jill, E. C. Impact of $16 \mathrm{~S}$ rRNA Gene Sequence Analysis for Identification of Bacteria on clinical Microbiology and Infectious Diseases. Clin Microbiol Rev. 2004; 840-862.

22. Woese, C. R., Stackebrandt, E., Macke, T. J., and Fox, G. E. A phylogenetic definition of the major eubacterial taxa. Syst Appl Microbiol. 1985; 6: 143-151.

23. Makolo, D., Suleiman A. B., Olonitola O. S., Bello, M., Isiyaku, A., Awulu, F. O., Aliyu, Y., Hammuel, C., Enenya, R. P., and Itua, M. P. Prevalence of Mastitis in Lactating Bovines and Associated Coliforms among Selected Pastoral Herds in Parts of Kaduna State, Nigeria. Acad J Life Sci. 2019; 5 (1): $1-9$.

24. Taiwo, L. B., Ailenokhuoria, B. V., and Oyedele, A. $O$. Profiling Rhizosphere Microbe on the Root of Maize (Zea Mays) Plated in an Alfisol for Selection as Plant Growth Promoting Rhizobacteria (PGPR). Microbiol Res J Int. 2017; 21 (5): 1-10.

25. Mbuk, E. U., Kwaga, J. K. P., Bale, J. O. O., Boro, L. A., and Umoh, J. U. Coliform organisms associated with milk of cows with mastitis and their sensitivity to commonly available antibiotics in Kaduna State, Nigeria. J Vet Med Ani HIth. 2016; 8 (12): 228-236.

26. Junaidu, A. U., Salihu, M. D., Tambuwala, F. M., Magaji, A. A., and Jaafaru, S. Prevalence of mastitis in lactating cows in some of selected commercial dairy farms in Sokoto Metropolis. Pela Adv Appl Sci Res. 2011; 2 (2): 290-294.

27. Agunbiade, T. B., Umoh, V. J., Whong, C. M. Z., and Ella, E. E. Assessment of Bovine Milk Obtained from Selected farms in Zaria Environs for Toxigenic Strains of Escherichia coli. Acad J of Life Sci. 2015; 1 (1): 8-13.

28. Hempen, M., Unger, F., Muntermann, S., Seck, M. T., and Niamy, V. "The hygienic status of raw and sour milk from smallholder dairy farm and local market and potential risk for public health" in The Gambia, Senegal and Guinea. Animal Health Research Working Paper 3. ITC (International Trypanotolerance Centre), Banjul, the Gambia. 2004:54.

29. Lingathurai, S., and Vellathurai, P. "Bacteriological quality and safety of raw cow milk in Madurai". South India. 2010 http://www.webmedcentral.com/article view/1029

30. Podder, M. P., Rogers, L., Daley, P. K., Keefe, G. P., Whitney, H. G., and Tahlan, K. Klebsiella species associated with bovine mastitis in Newfoundland. PLoS One. 2014; 9 (9): 106518.

31. Centre for Disease Control (CDC). Emerging and Zoonotic Infectious Diseases. https://www.cdc.gov/ncezid/index.html.

32. Food and Agriculture Organization (FAO). Milk hygiene in milking, milk production hygiene and 
udder health. FAO Animal Production and Health Papers-78. FAO Corporate Document Repository (CDR). 2008:1-7.

33. Food and Agricultural Organization of the United Nations (FAO). Milk, whole fresh cow producers. 2016
34. Claeys, W. L., Sabine, C., Geroges, D., et al. Raw or heated cow milk consumption: Review of risks and benefits. Food Contr. 2013; 31 (1): 251-262.

35. Bynum, J. Coliforms: Dangerous Biological Bioterrorism Agents. The Watch. 2011:1-81. 